\title{
膀胱腫瘍浸潤度診断に関する臨床的研究
}

$\begin{array}{ccccc} & \text { 黑 } & \text { 田 } & \text { 恭 } & \text { 一* } \\ \text { 金沢大学医学部泌尿器科学教室 } & \text { 津 } & \text { 川 } & \text { 龍 } & \text { 三** } \\ \text { (主任 : 黑田教一教) } & \text { 美 } & \text { 川 } & \text { 郁 } & \text { 夫 }^{* * *}\end{array}$

\section{CLINICAL STUDIES ON STAGING OF BLADDER TUMORS}

\author{
Kyoichi Kuroda, Ryuzo Tsugawa \& Ikuo Mikawa \\ From the Department of Urology, School of Medicine, Kanazawa University
}

(Director: Prof. K. Kuroda)

For the choice of the surgical treatment of bladder tumors, the depth of infiltration is an important factor. In order to diagnose the staging of tumors, the authors made such examinations to the patients as cystoscopy, intravenous pyelography, contrast cystography, cystopolygraphy, perivesical gas insufflation with tomography, pelvic anteriography and bimanual palpation under anesthesia.

Cystoscopy and intravenous pyelography are routine methods in the general urological procedures, and they are also very important methods to decide the staging. Cystoscopy is useful for the observations of the surface of tumors (specially papillary or not) and pedicle. When tumors are situated near the ureteral orifice and the renal functions are normal by intravenous pyelography, the tumors are all included in the stage $\mathrm{O}, \mathrm{A}$, and $\mathrm{B}_{1}$. When tumors are far from the ureteral orifice, it is not so useful. There is no relation between Constantinesco phenomenon and the staging. In contrast cystography, some projections (anteroposterior, basal, axial, dorsal) are needed to make tumors come out clearly. So cystography was performed as the means of those projections. As a result, axial and dorsal cystography is the most effective, because bladder tumors grow frequently near the ureteral orifice. In other words, it is important to project to the tumor mass tangentially on X-ray films. This opinion is a fundamental viewpoint to all roentgenological diagnosis of bladder tumors. In case of contrast cystography, observations were made as for symmetry and filling defect. When it showed especially imcomplete defect, all cases belonged to the stage $\mathrm{O}, \mathrm{A}$, and $\mathrm{B}_{1}$.

VUR is useless for the diagnosis of the staging.

In cystopolygraphy, the Temeliescu's method and the modification of the Connolly's method were used. The way of the latter is as follows: the contrast medium was limited to $80 \%$ of the bladder capacity as the maximum volume, and first $1 / 9$ of it, next $1 / 3$ and then the whole quantity were injected in order. Consequently, it is considered that the latter method is better than the former. To examine thickness of the wall, tomography in combination with pneumocystography and perivesical gas insufflation is of high diagnostic value to the tumor which situates at the lateral wall. Especially it is good for differentiation of C, D, or not. Pelvic arteriography has no need to be performed in all cases, but it is useful for the differentiation between $\mathrm{C}$ and $\mathrm{D}$.

Bimanual palpation under anesthesia is not so useful in our cases.

As we have seen, it is concluded that each method has its own peculiarity and that it is important to combine some suitable methods systematically, considering carefully the condition of the site of tumors within the bladder.

\footnotetext{
* 教授 ***講師 $* * *$ 助手
} 


\section{I. 緒言}

膀脂腫瘍の治療法は，現在，腫湯に対する根治性を指 向しつつ，一方に和いて代用浐胼，尿路変更に未解決の 点が多く, 結局は再発の可能性を残しながら膀腃の保存 をも考虑に入れざるを光ないといら矛盾を抱光，これを ぞのように解決し, 患者の生命の延長をはかるかといら きわめて困難な問題に直面している．この問題について の討議は昭和 42 年の日本泌尿器科学会総会でもなされ ${ }^{1)}$, 症例に応じて前記 2 つの面を考慮した上で最も良い方法 をとるべきことが強調されている，症例に応じてという ことのうち, 最も決定的な要素は, 浸潤度であると考兄 られ，この正確な判断が，内視鏡的治潦法をはじめ，全 摘除，西るいは手術を断念する場合を含めて，各種治療 法の展開の起点となるものと思われる.

この観点に立つて私共は従来から膀胼腫瘍の診断, 特 にX線診断法につき，しばしば発表してきた。

本論文に扮いては, これらの検査法はもらろん, 現在 までに routine work として行なわれてきた各検查法 （表1)を壁内浸潤度の面から再検討し, 私共なりの「最

表 1

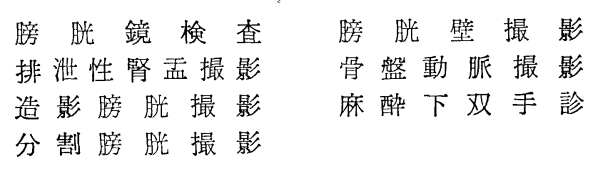

も効果的な浸潤度診断法」について述べたいと思う。な お対象とした症例はすべて教室経験例で，浸潤度につい て充分検索が可能であつたものに限定し, それ以外の症 例は除外した。な和浸潤度についてはOとAについては まとめて一群とした。また刘像例に行なわれた検査法の らち，たとえば骨盤動脈撮影のごとく，最近になつて加 えられたものもあり, 結果としては症例により検査項目 数がまちまちであるため, 同一浸潤度の群別に検査法を 論ずることは困難であるので, 検査法別に私共の方法, 成績, 見解などについて述べたのち, 項目を变えて考察 を行なつてみたい。

\section{II. 各検查法について}

1. 膀胱鏡検查所見と浸潤度との関係

本検查法は日常最もしばしば，また早期に行なわれる 外来検查法の1つである。したがつてこの所見が浸潤度 とどのような相関関係を示すかを知ることは重要な問題 である。一般に膀胱腫瘍の内視鏡的所見は，大きさ， 数, 表面の性状, 茎の有無, 周囲粘膜の態度などがチェ
表 2 腫瘍の大きさと浸潤度

\begin{tabular}{|c|c|c|c|c|c|}
\hline 大きさ 浸潤度 & $\mathrm{O} \sim \mathrm{A}$ & $\mathrm{B}_{1}$ & $\mathrm{~B}_{2}$ & $\mathrm{C}$ & $\mathrm{D}$ \\
\hline 小豆大まで & 6 & 0 & 0 & 0 & 0 \\
\hline 雀卵大まで & 17 & 2 & 0 & 0 & 0 \\
\hline 鳵卵大まで & 18 & 10 & 3 & 4 & 1 \\
\hline 鷄卵大まで & 5 & 1 & 1 & 6 & 3 \\
\hline それ以上 & 2 & 1 & 1 & 2 & 4 \\
\hline
\end{tabular}

表 3 腫瘍の数と浸潤度

\begin{tabular}{|cc|c|c|c|c|c|}
\hline \hline 数 & 浸潤度 & $\mathrm{O} \sim \mathrm{A}$ & $\mathrm{B}_{1}$ & $\mathrm{~B}_{2}$ & $\mathrm{C}$ & $\mathrm{D}$ \\
\hline 単 & 発 & 25 & 9 & 3 & 11 & 7 \\
\hline 多 & 発 & 23 & 4 & 2 & 2 & 1 \\
\hline
\end{tabular}

ックされる。まず腫瘍の大きさを観察でさた87例につい て大別してみると, 表 2 のごとくで, 雀畉大までの腫瘍 であれば浸潤は浅いとみてよいが，鳩卵大から鶏卵大に なるとバラッキを示し，筋層に浸潤が波及したものとの 区別は困難となつてくる。私共の症例の 4 割強が，その 程度の大きさに属しているといらことは, 実際問題上応 用価值が少ないとい壳る. 次弾発か多発かが, 浸潤度 診断にぞの程度意義があるものかを調查すると表 3 のご とくであり, 浸潤度の深いものは単発が多く, 多発のも のは浅い浸潤を示す．次に表面の性状との関係について みると, 表 4 のごとくで, 乳頭状か否かによつて浸潤度

表 4 腫瘍表面の性状と浸潤度

\begin{tabular}{|c|c|c|c|c|c|}
\hline $\begin{array}{c}\text { 表面 浸潤度 } \\
\text { 性状 }\end{array}$ & $\mathrm{O} \sim \mathrm{A}$ & $\mathrm{B}_{1}$ & $\mathrm{~B}_{2}$ & $\mathrm{C}$ & $\mathrm{D}$ \\
\hline 乳 頭 状 & 41 & 7 & 2 & 2 & 0 \\
\hline 非 乳 頭 状 & 4 & 7 & 3 & 8 & 10 \\
\hline
\end{tabular}

は大いに異なつてくる，乳頭状のものでは，臨床的にい わゆる浅い浸潤㐿するものが52例中48例を占め, 非乳 頭状にみ兄るものは32例あり, 浅い浸潤に属するものは 11例にとどあるが，なお非乳頭状であることのみで深い 浸潤であるとはい学ない，次腫瘍が有茎であるか広基 であるかといらことと浸潤度との関係であるが, 表 5 の ごとくで, 有茎のものは浸潤が浅く, 広基のものに深い 浸潤がみられることが多いことが確認された。なおこの 問題については大北 ${ }^{2)}$ か詳細に述べている. 周囲粘膜と の関係は表 6 のごとくで, 正常であれば浸潤は低いとみ てよいが, その逆, すなわち浮腫, 発赤の存在が深い浸 
表 5 腫場菱の有無と浚潤度

\begin{tabular}{|cc|c|c|c|c|c|}
\hline \begin{tabular}{|c|c|c|c|c|}
\hline 茎の \\
有無
\end{tabular} & 浸潤度 & $\mathrm{O} \sim \mathrm{A}$ & $\mathrm{B}_{1}$ & $\mathrm{~B}_{2}$ & $\mathrm{C}$ & $\mathrm{D}$ \\
\hline 有 & 茎 & 35 & 4 & 1 & 3 & 0 \\
\hline 広 & 基 & 3 & 10 & 4 & 8 & 9 \\
\hline
\end{tabular}

表 6 周国粘膜の状態と漫潤度

\begin{tabular}{|c|c|c|c|c|c|}
\hline $\begin{array}{c}\text { 粘膜 浸潤度 } \\
\text { の状態 }\end{array}$ & O A & $\mathrm{B}_{1}$ & $\mathrm{~B}_{2}$ & $\mathrm{C}$ & $\mathrm{D}$ \\
\hline 正 & 34 & 5 & 3 & 4 & 0 \\
\hline 病 変む り & 6 & 7 & 2 & 7 & 7 \\
\hline
\end{tabular}

表 7 腫湯の性状と浸潤度

\begin{tabular}{|c|c|c|c|c|c|}
\hline $\begin{array}{l}\text { 腫瘍 漫潤度 } \\
\text { 力性状 }\end{array}$ & $O \sim A$ & $\mathrm{~B}_{1}$ & $\mathrm{~B}_{2}$ & $\mathrm{C}$ & D \\
\hline 乳頭状有茎 & 35 & 4 & 1 & 2 & 0 \\
\hline 非乳頭状広基 & 2 & 7 & 3 & 7 & 10 \\
\hline
\end{tabular}

潤を常に示するのではない，

ここで，表面の性状が乳頭状でかつ有茎で㠰る42例を 集めてその浸潤度をみると表 7 のごとくになる。すなわ ら，乳頭状有茎であれば，その83\%はO〜Aに属してい ることになる。逆に非乳頭状でから広基にみ光るるのは 29例あるが，このうちO〜 A 2 例のみで，27例は $\mathrm{B}_{1} か$ らDに属し, 筋層への浸潤が沶よぶものが, 汪とんどで あることがわかる，以上から初診時膀胱鏡検査に打ける 詳細な観察は, 浸潤度判定の上できわめて重要な資料を 提供することが再確認され，腫瘍の存在のみを確認して 検査を終えることがあつてはならないことを示してい る。な打本検査は, 高度血尿例, 閉塞性尿道疾患例など では施行不能で，一定の制約があるのが難点である.

2 , 排泄性腎孟撮影所見と浸潤度との関係

私共の日常実施している撮影方法は，尿管圧迫带を使 用し，76\% Urografin などの造影剤 $20 \mathrm{ml}$ を静注し， 7 分㧍よび15分目に腎部を撮影したのち，圧迫带をはずし て10分後に腎から焪脱全体にわたり 1 枚撮影といら順序 である。な报痁例によつては傾斜法をとつたものるあ る。

本法の所見は腫瘍の存在部位が尿管口付近であるか否 かによつて左右されることが予想されるので, 腫瘍の存 在部位によつて分類したところ表 $8 ， 9$ のごとくにな
表 8 排泄性腎孟撮影 (IVP) と浸潤度 （腫瘍が尿管口付近にあるもの）

\begin{tabular}{|cc|c|c|c|c|c|}
\hline \begin{tabular}{|l|r|r|} 
IVP \\
機能
\end{tabular} & 浸潤度 & $\mathrm{O} \sim \mathrm{A}$ & $\mathrm{B}_{1}$ & $\mathrm{~B}_{2}$ & $\mathrm{C}$ & $\mathrm{D}$ \\
\hline 良 & 好 & 24 & 3 & 0 & 0 & 0 \\
\hline 不 & 良 & 7 & 2 & 1 & 3 & 0 \\
\hline
\end{tabular}

表 9 排使性腎盘撮影 (IVP) と浸潤度 （腫瘍が尿管口より離れているもの）

\begin{tabular}{|cc|c|c|c|c|c|}
\hline $\begin{array}{r}\text { IVP } \\
\text { 機能 }\end{array}$ & 浸潤度 & $\mathrm{O} \sim \mathrm{A}$ & $\mathrm{B} 1$ & $\mathrm{~B} 2$ & $\mathrm{C}$ & $\mathrm{D}$ \\
\hline 良 & 好 & 14 & 8 & 3 & 6 & 3 \\
\hline 不 & 良 & 1 & 1 & 1 & 3 & 5 \\
\hline
\end{tabular}

る.腫瘍が尿管口付近にあつて腎機能が良好なものは 27 例あり， $\mathrm{O} \sim \mathrm{A}$ が 24 例， $\mathrm{B}_{1}$ が 3 例である. 逆に尿管口 付近に腫瘍があつて，腎機能不良な場合にも浅い浸潤を 示すものがあるが，これらの例は腫瘍の大きさが大きい 方に属する. 形態についていえば，尿管口付近に腫瘍の ある40例のうち，その側の形態が正常であるもの28例中 24例が $\mathrm{O} \sim \mathrm{A}$ に属している。一方尿管口付近から離れた 位置にあるものは，浸潤の深い汪ど異常を示す傾向はあ るにせよ，形態正常例についてはとの浸潤を推論するこ とはでさない。結局，排泄性腎孟撮影（以下 IVP と略 称）を浸润度診断法として考光るとき，腫痬が尿管口付 近位置する際にきわめて有力な判定手段であるとい兄

表10 Constantinesco 現象と浸潤度

\begin{tabular}{|c|c|c|c|c|c|c|}
\hline & \begin{tabular}{|l} 
浸潤度璄 \\
の位置
\end{tabular} & $\mathrm{O} \sim \mathrm{A}$ & $\mathrm{B}_{1}$ & $\mathrm{~B}_{2}$ & $\mathrm{C}$ & $\mathrm{D}$ \\
\hline \multirow{2}{*}{$(-)$} & 尿管口付近 & 16 & 2 & 1 & 1 & 0 \\
\hline & $\begin{array}{l}\text { 尿管口より } \\
\text { 離れる }\end{array}$ & 14 & 5 & 0 & 5 & 4 \\
\hline \multirow{2}{*}{ t) } & 尿管口付近 & 1 & 1 & 0 & (対側) & 0 \\
\hline & 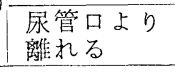 & 0 & 2 & 0 & (対側1) & 0 \\
\hline
\end{tabular}

るが，膀脱腫瘍は尿管口付近に発生することが多いの で，IVP のもつ意義は実際上きわめて大きい，次にこ のような IVP 異常所見の前段階として, Constantinesco 現象がぞの程度意義あるかを調査したが，結果は表10の ごとくで有用ではないことが判明した。

IVP の意義については既に辻3) らの研究によつて強 調されているが，私共は上述のごとく，特に尿管口付近 
に復在する際の有用性を確認した。なお IVP 時に得ら れる前後方向の膀脂像は, 次項の造影膀胱像に比して言 断的価値は小さい。

3. 造影膀胱撮影所見と浸潤度との関係

本法に扮いて重要かつ根本的なことは，いかにして蕾 瘍を描出するかである。その一法としての撮影体位の研 究は高安ら ${ }^{4) 5}$ とよつて行なわれている.私共も膀胱嘎痬 例に対しては原則として 4 方向で撮影しているが，現在

表11腫瘍の位置と良し造影体位（ベスト2）

\begin{tabular}{|c|c|c|c|c|c|}
\hline \multirow{2}{*}{\multicolumn{2}{|c|}{ 体位 }} & 頂 部 & 後 壁 & 側 壁 & \\
\hline & & 9例 & 48 & 17 & 2 \\
\hline 前 & 後 & 10点 & 22 & 16 & 2 \\
\hline 底 & 部 & 1 & 0 & 2 & 0 \\
\hline 軸 & 性 & 3 & 61 & 18 & 3 \\
\hline 背 & 面 & 9 & 47 & 12 & 1 \\
\hline
\end{tabular}

までの施行例について腫瘍の描出率を点数をつけて表示 してみた，最も良い描出を示す体位を 2 点，次のものを 1点とした（一方向のみ良好なものはそのフイルムを 2 点）が, 結果は表11のごとくで, 注目される事実は, 習 慣的に前後方向で行ないがちな造影膀胱撮影は, 頂部, 側壁に存在するものには有用であるが，最も多くみられ る後壁から三角部にかけての腫瘍の描出には軸性撮影と 背面撮影が適していることである．腫湯を tangential に，フイルム上に忠実に投影しょうとする考光方は，す べてのX線学的浸潤度診断の基本となるものであ党てこ こに表示した。

次に上記体位で撮影して得られた最も描出の良いフイ ルムで観察した場合，チェックすべき点は膀胱像の左右 対称性と陰影欠損の状況であると考学られる。まず左右 対称性であるが，表12のごとく左右刘称性であると判定 したものは43例あり，そのうち34例まではO〜Aに属す るが，深い浸潤を示すものもあり，これらの例は頂部に 存在する. 非対称的な 31 例中 6 例は $\mathrm{O} \sim \mathrm{A}$ に属し，これ らの発生部位は尿管口付近から側壁にかけてであり，か つ腫瘍の大きさは鳩卵大以上であつた．次に陰影欠損と

表12 造影膀胱像の対称性と浸潤度 (4方向を含生)

\begin{tabular}{|c|r|r|r|r|r|}
\hline 対称性 浸潤度 & $\mathrm{O} \sim \mathrm{A}$ & $\mathrm{B}_{1}$ & $\mathrm{~B}_{2}$ & $\mathrm{C}$ & $\mathrm{D}$ \\
\hline$(+)$ & 34 & 6 & 0 & 3 & 0 \\
\hline$($ ( ) & 6 & 7 & 1 & 9 & 8 \\
\hline
\end{tabular}

表13 院影欠損と漫潤度

\begin{tabular}{|c|c|c|c|c|c|}
\hline 陰影浸潤度 & $\mathrm{O} \sim \mathrm{A}$ & $\mathrm{B}_{1}$ & $\mathrm{~B}_{2}$ & $\mathrm{C}$ & $\mathrm{D}$ \\
\hline 不完全欠損 & 30 & 6 & 0 & 0 & 0 \\
\hline 完 全欠 損 & 5 & 4 & 2 & 12 & 8 \\
\hline
\end{tabular}

表14 V UR と浸潤度

\begin{tabular}{|c|c|c|c|c|c|}
\hline $\mathrm{V} \mathrm{UR}$ 浸潤度 & $\mathrm{O} \sim \mathrm{A}$ & $\mathrm{B}_{1}$ & $\mathrm{~B}_{2}$ & $\mathrm{C}$ & $\mathrm{D}$ \\
\hline$(-)$ & 25 & 11 & 3 & 6 & 2 \\
\hline$(+)$ & 11 & 1 & 1 & 5 & 1 \\
\hline
\end{tabular}

浸潤度との関係について述べる. 本法による所見は不完 全欠損と完全欠損に分けられる。各群について浸潤度別 にみると，表13のごとくになる。すなわち36例中30例が $\mathrm{O} \sim \mathrm{A}$ に属し，他は $\mathrm{B}_{1}$ 飞属し，臨床的にいらいわゆる 浅い浸潤に全例入ることになる。一方完全欠損群31例の 内訳はな特バラッキがあり，腫瘍が有茎で浅い浸潤を示 していても，完全欠損として描出されている．以上から 不完全欠損を示せば次の検查に進むことはまず不要と考 えてもよいが，完全欠損を示す例は，次の検査を計画す ると同時にそれまでに行なわれた検査を再吟味せねばな らない． Emmett ${ }^{6)}$ も造影膀脱像に抢汗る所見として欠 損状況の特徴として，いくつかを挙げている。

次に VUR と浸潤度の関係沉ついて調査してみると, 表14のごとくで, 浸潤度別に VUR 陽性例と陰性例を比 較しても一定の傾向は認められない. 次に VUR 陽性例 についてみると，腫瘍存在側の尿管に陽性のもの 7 例， 対側の尿管に陽性のもの 6 例で, 他は両側飞陽性を示 し，また腫崵の部位（尿管口付近など）とも全く関係が 尔い。この点については既に当教室の酒井7)が発表した が，むしろ併発した炎症に上るといら考方方が多い。

4. 分割膀胱撮影所見と浸潤度との関係

膀脱壁の伸展性を造影剂の增量といら負荷を加えるこ とによつて観察する本法は原理的にきわめて興味深いも のがある．当教室に和ける本法の実施は1960年から1966 年にかけては Temeliescu的の原法を行なつていたが， 1967年から1968年にかけては Connolly ${ }^{910)}$ の報告した 方法㲹改良を加光た方法 (一応 Connolly の変法 ${ }^{11}$ ) 称

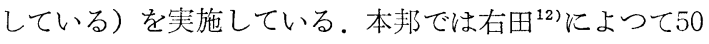
例を対象とした報告がり，その他，Simons ${ }^{13)}$, Köhler $\left.{ }^{14)}, \mathrm{Cobb}^{15}\right)$ の報告がある。実施法は Temeliescu の原法 
では，膀胱容量と関係なく $15 \mathrm{ml} ， 30 \mathrm{ml} ， 60 \mathrm{ml}$ の順で計 3 回同一フイルム上に曝射し体位は前後方向であるが, Connolly の原法は, 膀胱容量を 4 等分し, 順次容量を 增しつつ暴射し，その体位は前後方向の他に，斜位をと り入れるなど，前記のごとく腫痬に tangential になる ように工夫されている．私共の方法はこの方法に腫瘍描 出に最もよい体位を組反合わせることと，注入量を膀脱 容量の 8 割に止め, 造影剤注入による尿意促迫を防止す るように配虑し，この量を最大量として，最初はその $1 / 9$ 量, 次汇 $1 / 3$ 量, 最後に容量の 8 割の量として終了する. 体位は軸性方向であればな扮可能であるが，背面方向で の本法実施は，技術上困難で鮮明な像は得られない。結 果は表15，16のごとくで Connolly 変法は浸潤とよく一 致するが, Temeliescu 原法は伸展性がきわめて良好な群 は低い浸潤を示す結果となつたが，一応の伸展性が認め

表15 Temeliescu 原法と浸潤度

\begin{tabular}{|c|r|r|r|r|r|}
\hline 伸展性 $^{\text {潕潤度 }}$ & $\mathrm{O} \sim \mathrm{A}$ & $\mathrm{B}_{1}$ & $\mathrm{~B}_{2}$ & $\mathrm{C}$ & $\mathrm{D}$ \\
\hline$(+\mathrm{H})$ & 30 & 3 & 0 & 1 & 0 \\
\hline$(+)$ & 5 & 5 & 2 & 5 & 2 \\
\hline$(-)$ & 0 & 1 & 0 & 2 & 3 \\
\hline
\end{tabular}

表16 Connolly 変法と浸潤度

\begin{tabular}{|c|r|r|r|r|r|}
\hline 伸展性 浸潤度 & $\mathrm{O} \sim \mathrm{A}$ & $\mathrm{B}_{1}$ & $\mathrm{~B}_{2}$ & $\mathrm{C}$ & $\mathrm{D}$ \\
\hline$(\mathrm{H})$ & 3 & 0 & 0 & 0 & 0 \\
\hline$(+)$ & 2 & 1 & 1 & 0 & 0 \\
\hline$(-)$ & 0 & 0 & 0 & 4 & 2 \\
\hline
\end{tabular}

られるいわゆる（十）の群は19例あり，この群の浸潤度 はバラッキを示した。これは Temeliescu 原法では造影 剤増量の割合が少なく，充分な負荷がかからないことに よるものと考えられる.な和同一症例で 2 つの方法を比 ベてみたものは 4 例あるが，私共の行なつている Connolly 変法が明らかに優れていた。

5. 膀胼壁撮影听見と浸潤度との関係

膀脱周囲に気体を送入し，壁の描出を試みる本法は， 本邦では高安 ${ }^{16)}$, 千葉 ${ }^{17)}$ の研究があり, 診断上有用と報 告されている。な扬気体の送入法には異なる経路からの 報告 ${ }^{18}{ }^{19}{ }^{20}$ かかあり，それぞれ良好な成績を示している. 私共の方法は, 前尾胃法により酸素約 $600 \mathrm{ml}$ を送入し, 約 2 時間骨盤高位として拉く，膀脱内に $100 \mathrm{ml}$ の空気
を送入し，断層撮影を併用する. 大体背面から $9 \mathrm{~cm} \sim 14$ cmまでを $1 \mathrm{~cm}$ 間隔で撮影すれば充分である．観察すべき 点は壁肥厚, 壁外周の状態, 気体の侵入状況である. 壁 の肥厚は腫瘍塊の膨隆による陰影とは別個に慎重に判読 すべきものである。これを浸潤度別に一括して示すと表 17のごとくで，健康側と同様の厚さを示す21例をみる と，O〜 Aが15例， $\mathrm{B}_{1}$ を加えると20例がこれに相当し， 肥厚を示すものは14例でいずれも C またはDに相当し浸 潤を忠実に反映している。な打 C浸潤度を有しながら 壁肥厚を認めなかつた 1 例は, 前壁に存在したもので断 層撮影の死角に入つたためである. 壁外周の状態は気体 侵入の状況に大体一致するので，ここでは気体侵入の状 況と浸潤度の関係について示すと表18のごとくになる. すなわち良好なものは23例で，そのらちO〜Aで15例， $\mathrm{B}_{1}$ を入れると20例に達し，不良の場合は 12 例全体が $\mathrm{C}$

表17 壁肥厚と浸潤度

\begin{tabular}{|c|c|c|c|c|c|}
\hline 萌 厚 浸潤度 & $\mathrm{O} \sim \mathrm{A}$ & $\mathrm{B}_{1}$ & $\mathrm{~B}_{2}$ & $\mathrm{C}$ & $\mathrm{D}$ \\
\hline$(+)$ & 15 & 5 & 0 & 1 & 0 \\
\hline$(-)$ & 0 & 0 & 0 & 9 & 5 \\
\hline
\end{tabular}

表18 腫瘍部気体侵入状沉と浸潤度

\begin{tabular}{|cc|c|c|c|c|c|}
\hline \begin{tabular}{|c|c|c|c|c|} 
侵大 \\
状況
\end{tabular} & 浸潤度 & $\mathrm{O} \sim \mathrm{A}$ & $\mathrm{B} 1$ & $\mathrm{~B}_{2}$ & $\mathrm{C}$ & $\mathrm{D}$ \\
\hline 良 & 好 & 15 & 5 & 0 & 3 & 0 \\
\hline 不 & 良 & 0 & 0 & 0 & 7 & 5 \\
\hline
\end{tabular}

たはDに属している，問題となるのは，所見としては良 好でありながら深い浸潤を示した 3 例で，1 例は内尿道 口部前壁にあり，他の 2 例ではそれぞれ頂部，後壁に存 在したが，後二者は肥厚の有無をチェックした際に，浸 潤の存在を疑われている。

以上本法は浸潤度診断法としてきわめて有用ではある が，実際問題として，既往に手術を受けている症例では 周囲との癒着により気体の侵入がないため, 行なつても 意味がない。

6. 骨盤動脈撮影所見と浸潤度との関係

私共 ${ }^{21)}$ が既に発表したごとく，本法は最近注目されて きた方法である，Lang ${ }^{221}$ は多年にわたる本法の経験を 最近の Monograph に詳述している。私共の方法は 1 側 大腿動脈を利用しての Seldinger 法で第 4 腰椎の高さで 造影剂を注入し，10秒間の連続撮影で観察した。な抢原 
表19 骨盤動脈像 と浸潤度

\begin{tabular}{|c|c|c|c|c|c|}
\hline $\begin{array}{c}\text { 病理 } \\
\text { 学的 } \\
\text { 学的 }\end{array}$ & 例数 & $\mathrm{O} \sim \mathrm{A}$ & $\mathrm{B}$ & $\mathrm{C}$ & $\mathrm{D}$ \\
\hline $\mathrm{O} \sim \mathrm{A}$ & 8 & 8 & 0 & 0 & 0 \\
\hline $\mathrm{B}$ & 5 & 0 & 4 & 1 & 0 \\
\hline $\mathrm{C}$ & 5 & 0 & 1 & 4 & 0 \\
\hline $\mathrm{D}$ & 5 & 0 & 0 & 2 & 3 \\
\hline
\end{tabular}

則として膀胱周囲への酸素送入，膀胱内空気送入を併用 している. 結果は表19のごとくで，私共の判定基準で分 析し，浸潤度を推定したが，CとDとの鑑別に有用であ ることが判明した。このような鑑別診断は他の方法では できない。しかし体位については血管撮影を受ける患者 の状態を考虑に入れる必要があり，造影膀胱撮影のよら に行ならことは困難と考えられ，腫瘍発生部位によつて は診断的洒值は少ない。また年令的にも老人が多く, 動 脈硬化性変化によつて血管内にカテーテルを挿入できな い場合もありらる。

\section{6. 麻酔下双手䛦と浸潤度との関係}

本診断法は表200ごとき結果でバラツキがあり，私共 が対象とした例についてはあまり有用とは思われなかつ た。この問題については信頼性ありとする Jewett ${ }^{23)}$, 適

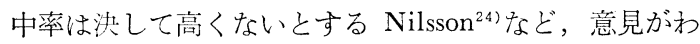

表20麻酔下双手䛦と浸潤度

\begin{tabular}{|c|c|c|c|c|c|}
\hline 所 見 浸潤度 & $\mathrm{O} \sim \mathrm{A}$ & $\mathrm{B}_{1}$ & $\mathrm{~B}_{2}$ & $\mathrm{C}$ & $\mathrm{D}$ \\
\hline 触 れ る & 2 & 1 & 1 & 4 & 6 \\
\hline 触れない & 21 & 3 & 0 & 5 & 0 \\
\hline
\end{tabular}

かれている. 私共の考えとしては, 麻酔をかけてはじめ て検査しらる本法は，実際問題として手術の直前に判明 することになり, 浸潤度診断法としては, 治療方針の選 定を術前充分に議論する材料にならず実用性に乏しい.

以上各方法について日常実施している方法および私共 の見解について記述した。これを簡単にまとめてみると 表21のごとくになる。

\section{III. 考 按}

緒言にも述べたごとく，本研究における私共の目的 は，与えられた症例に対し，各検査法をどのように行な えば迅速に浸潤度を知りらるかにある. 膀胱腫瘍患者に 対し, 早期治療をすすめる一方で, 多くの検査と侵襲を 加え, その間に腫瘍の増大，全身の消耗をきたすことは 避妆ばならない。しかし，検査法を整理して適当なる ののみを選ぶとしても，すべての検査法を充分に実施し た症例を検討してからでなければならない，私共の症例 中各検査を実施した 23例についてみると表22 のごとく で，きわめて浅い浸潤を示すものと，深い浸潤を示すも，

表21 各検査法の得失

\begin{tabular}{|c|c|c|c|}
\hline 検査法 & 診断的有用性 & 診断の限 界 & 簡便性その他 \\
\hline 膀胱鏡検査 & $\begin{array}{l}\text { 検査可能ならば全例 } \\
\text { 特にOA } \\
\text { 乳頭状有茎ならば特に明確 }\end{array}$ & $\begin{array}{l}\text { 内視鏡検査不能例あり } \\
\text { 非乳頭状広基ならばバラッ } \\
\text { キあり }\end{array}$ & 簡便でかつ即時確診も可能 \\
\hline $\begin{array}{l}\text { 排沘性腎需 } \\
\text { 撮影 }\end{array}$ & $\begin{array}{l}\text { 尿管口付近で機能形態正常 } \\
\text { ならば特に明確, OAに適 } \\
\text { す }\end{array}$ & $\begin{array}{l}\text { 買常所見を示すときあるい } \\
\text { は腫瘍が尿管口を離れてい } \\
\text { るときは困難 }\end{array}$ & 簡便 \\
\hline $\begin{array}{l}\text { 造影腾胱撮 } \\
\text { 影 }\end{array}$ & $\begin{array}{l}\text { 不完全欠損像に注目 } \\
\text { 全渗潤度特にOA }\end{array}$ & $\begin{array}{l}\text { 完全欠損像はな执決定的と } \\
\text { はいえない }\end{array}$ & $\begin{array}{l}\text { 腫瘍を最もよく描出できる } \\
\text { 体位で行な5べきである }\end{array}$ \\
\hline $\begin{array}{l}\text { 分割膀脂撮 } \\
\text { 影 }\end{array}$ & 全浸潤度 & $\begin{array}{l}\text { 生理的に伸展に限界ある部 } \\
\text { 分は不適当 }\end{array}$ & $\begin{array}{l}\text { 造影膀胱撮影と同時に行な } \\
\text { えるので簡便 } \\
\text { Connolly 変法が合理的 }\end{array}$ \\
\hline 膀胱壁撮影 & $\begin{array}{l}\text { 肥厚および気体侵入不良 } \\
\text { 所見, 全浚潤度特にCD }\end{array}$ & $\begin{array}{l}\text { 前壁部のものには不適当 } \\
\text { 手術既往例には不適当 }\end{array}$ & $\begin{array}{l}\text { 気体送入操作を要しやや不 } \\
\text { 便 }\end{array}$ \\
\hline $\begin{array}{l}\text { 骨盤動脈撮 } \\
\text { 影 }\end{array}$ & $\begin{array}{l}\text { 周囲組織との関係の判定特 } \\
\text { にCDD }\end{array}$ & 明瞭な血管像を必要とする & $\begin{array}{l}\text { 手技にやや時間がかかる } \\
\text { 動脈硬化症例には不適 }\end{array}$ \\
\hline $\begin{array}{l}\text { 麻酔下双手 } \\
\text { 䛦 }\end{array}$ & $\begin{array}{l}\text { 部位が適当であれば有用特 } \\
\text { にCDD }\end{array}$ & $\begin{array}{l}\text { 麻酔をかけた場合のみ施行 } \\
\text { 可能 主観的 }\end{array}$ & 施行は簡便 \\
\hline
\end{tabular}


表22 各検査法の優劣（各検查法すべてを行な つた最近の症例)

\begin{tabular}{|c|c|c|c|c|}
\hline 検查法 漫潤度 & $\mathrm{O} \sim \mathrm{A}$ & $\mathrm{B}_{2}$ 症例な乙 & $\mathrm{C}$ & D \\
\hline 例 数 & 8 & 5 & 5 & 5 \\
\hline 膀 脱 鏡 檢 查 & H & + & + & $H$ \\
\hline 排泄性腎孟撮影 & H & + & + & + \\
\hline 造影膀胱 撮影 & H & $H$ & $H$ & $H$ \\
\hline 分 割膀胱撮影 & H & + & $H$ & $H$ \\
\hline 膀脱壁 撮影 & H & $H$ & $H$ & H \\
\hline 骨壁動脈撮影 & H & $H$ & $H$ & $H$ \\
\hline 麻醉下双手診 & + & - & - & $H$ \\
\hline
\end{tabular}

表23 膀胼腫瘍症例についての検査順位

\begin{tabular}{|c|c|c|c|}
\hline $\begin{array}{l}\text { 迸択順位 } \\
\text { 膀譄鏡 } \\
\text { 所睍 }\end{array}$ & I & II & III \\
\hline & IVP & $\begin{array}{c}\text { 造影膀胱 } \\
\text { 及 } \\
\text { 分割膀胱 }\end{array}$ & 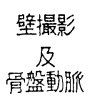 \\
\hline & $\begin{array}{l}\text { 造影膀胱 } \\
\text { 及 } \\
\text { 分割傽脱 }\end{array}$ & 壁撮影 & 骨盤動䐚盾 \\
\hline & $\begin{array}{l}\text { 造影䏽胱 } \\
\text { 及 } \\
\text { 分割膀胱 }\end{array}$ & 骨盤動服 & 壁撮影 \\
\hline & 骨盤動脈 & $\begin{array}{c}\text { 造影傽脱 } \\
\text { (前後背面) }\end{array}$ & \\
\hline $\begin{array}{l}\text { 施 行 } \\
\text { 不能 }\end{array}$ & IVP & $\begin{array}{l}\text { 造影膀胱 } \\
\text { 及 } \\
\text { 分割膅胱 }\end{array}$ & 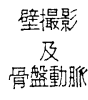 \\
\hline
\end{tabular}

のでは，どの方法をとつてみても診断的価值はあるが， B あるいはCの診断には症例ごとに適応を考兄る必要が あると思われる。 また患者の立場で考光た場合，もし同 等の診断的価値があるものであれば実施が簡単で, 苦痛 の少ないものを選定すべきであろう．私共はこの考光方 から最もよく遭遇するケースを想定して表23のごとくに まとめてみた。たと艺ば腫瘍の好発部位である膀胱後壁 尿管口付近についてい衤ば, 膀脱鏡検查所見で, 乳頭状 有茎であれば，そのあとは排泄性腎孟撮影と，造影膀脱 撮影（軸性和よび背面方向）を行ない，前者が正常所 見，後者が不完全陰影欠損を示すならばまず浸潤は浅い として差支兑ない。またこれらの検查法で異常所見があ るときは，C・Dの可能性ありとして壁撮影と骨盤動脈撮
影心進む必要がある。ただし，この場合も腫恒がフイル ム上飞 tangential に投影されることが必要で，できれ ば撮影体位を斜位とするなどの配慮を要する。また腫瘍 が側壁にあれば，前後方向で行ならX線学的各検査法は 腫境が tangential 飞投影されている結果，きわめて効 果的である。一方頂部についてみると, 造影膀胱撮影お よび分割膀胱撮影は有用であるが，骨盤動脈撮影は私共 の症例では病変を示し難く, 壁撮影もまた同様で, カス の侵入は不良であり，とき腸管の陰影が重なつて浸潤 度の読影は困難である。また前壁の場合は骨盤動脈像が 唯一の浸潤度診断の根拠となつた例があるが，やはり膀 脱鏡所見が最も有用である。

結局，各検査法を通じてみた場合，浸潤度診断につい て最も簡単で，欠くべからざる方法は依然として膀脱鏡 検査であり，充分な観察力を養らことが必要である. 元 来膀腃腫瘍はその時点での浸潤にとどまらず，さらに進 行する例が多いことはいらまでもないが，X線学的方法 はその時点での診断にとどまり，将来どのように浸潤が 進むかの想定は，全く新しい創意をもちこまない限り困 難であろう。この意味で膀胱鏡検査による腫瘍の性状の 観察は, ある程度の予知が可能であることは前述した。 さらに観点を変えて，切除範囲決定に必要ないわゆる水 平方向への拡がりの診断法に関しては，な捈討の余地 がある。またIVP も腫瘍存在部位によつては浸潤度診 断法としてきわめて優れていることも再確認された。こ の点は Lang の Monograph にも詳しい. 造影膀羘撮影 も撮影体位を検討すれば高い診断適中率を得ることがで きるし，また筋層あるいはそれを貫通する浸潤に対して は膀胱鏡検査はむしろ意義はなく, 分割膀脂撮影, 壁撮 影が有用であり, 周囲組織との関係については, 骨盤動 脈撮影が適応となる。すなわち現在における漫潤度診断 はこれら各方法の特徵を合理的に組み合わせて行なわれ るべさである。

さて, 膀胱腫瘍の臨床病理学的観察に必要な今 1 つの 問題はいわゆる悪性度で, この検索は主として生検法に より行なわれている. 従来, 生検標本によつて浸潤度を も判定する試みがなされているが，実際の浸潤度よりも 軽度にみられることが多いとされている。しか子筋層へ の浸潤のある腫瘍で，正しい診断を下しうるには，技術 的には第孔の危険を括かして操作せ祆ばならないし，出 血その他で術後管理に困難を伴う。したがつて現在の私 共の立場として，生検は主目的としては腫瘍の種類拉よ び覀性度判定のために行ない，浸潤度の診断は本稿に述 
べた方法によつて行ならべきであると考えている。

\section{IV. 結 語}

膀胱腫瘍の治療方針決定ならびに予後判定上さわめて 重要視される浸潤度診断法に関し，私共の行なつている 方法, すなわち膀胱鏡検査, 排泄性腎血撮影, 造影膀脱 撮影, 分割膀胱撮影, 膀胱壁撮影, 骨盤動脈撮影および 麻酔下双手診の診断的価值を比較検討した成績について 記述した。

膀胱鏡検查および排泄性腎孟撮影は，漫潤度を決める 上においても不可欠の方法である。また深い浸潤を示す 症例に打汁る周聿組織との関係を知る手段としては骨盤 動脈撮影が適当である. 臨床的立場よりみて, 最も迅速 かつ確実に，しかも患者に必要以上の負担を与党ること なく浸潤妄を判定するためには，上記各検査法の特徵を 充分理解し，かつ腫瘍存在部位などの条件を考慮に入れ た上で，適当な方法を順序よく組み合わせることが重要 であることを強調したい。

(本論文の要旨は第56回日本泌尿器科学会総会におい て発表した。な扮本研究の一部は文部省科学研究費〔総 合研究】によつた。記して謝意を表する)

\section{文献}

1）突戸ら：第55回日本泌尿器科学会総会シンポシ ウム, 日泌尿会誌, 58, 938, 1967.

2) 大北：臨泌, 21, 765, 1967.

3) 辻：日本泌尿器科全書, 5, 金原出版. 南江堂,
東京, 1960 .

4) 高安ら：日泌尿会誌，44，123，1953.

5）高安ら：日泌尿会誌，46，711，1955.

6) Emmett, J.L.: Clinical Urography II, W.B. Saunders, Philadelphia, 1964.

7）酒井：日泌尿会誌，58，957，1967.

8) Temeliescu, I.: Urol. Int., 7, 285, 1958.

9) Connolly, J.G. et al.: Canad. J. Surg., 9, 39, 1966.

10) Connolly, J.G. et al.: J. Urol., 98, 356, 1967.

11）津川ら：日癌治, 3,126, 1968.

12) 右田：福岡医誌, 56, 189, 1965.

13) Simons, E.: Zschr. Urol., 57, 497, 1964.

14) Köhler, K. et al.: Zbl. Chir., 90, 2230, 1965.

15) Cobb, O.E. et al.: J. Urol., 94, 569, 1965.

16) 高安ら：日泌尿会誌, 44, 87, 1953.

17）千葉：日泌尿会誌，54，1175，1963.

18) Bartley, O. et al.: Acta Radiol., 54, 241, 1960.

19) Gosalbez, R. et al.: J. Urol., 88, 312, 1962.

20) Soifer, E. et al.: J. Urol., 89, 759, 1963.

21）黒田ら：日泌尿会誌，58，217, 1967.

22) Lang, E.K.: Roentgenographic Diagnosis of Bladder Tumors, Charles C Thomas Publisher, Spring field. Illinois, 1968.

23) Jewett, H.J.: J. Urol., 49, 34, 1943.

24) Nilsson, A.E.: Acta Chir. Scand., 115, 132, 1958.

（昭和 43 年 7 月 1 日受付） 